\title{
XI CHAN KIRGISTANU. KURMANBEK BAKIJEW, RZĄDY RODZINNE I HEROIZACJA PRZESZŁOŚCI
}

\author{
WPROWADZENIE
}

W ciągu swoich pięcioletnich rządów (2005-2010) rodzina Bakijewów, będąc zarówno produktem, jak i reżyserem fuzji formalnych i nieformalnych wymiarów władzy, systematycznie naruszała trójpodział władzy. Członkowie rodziny byli głównym ośrodkiem, czy ośrodkami decyzyjnymi, władając krajem niemal jak udzielni książęta. Dla uprawomocnienia swej dominującej pozycji systematycznie reinterpretowywali przeszłość. Poszukując w przeszłości genezy swego szlachetnego pochodzenia, ugruntowywali pozycję potrzebną dla określania kształtu przyszłości. Wnikliwą uwage poświęcali także rewolucji tulipanowej. Dojście do władzy Kurmanbeka Bakijewa wraz z liczną familią miało ustanowić nowy punkt zwrotny w najnowszej historii Kirgistanu. Oficjalna historiografia opisywała ją jako rewolucję narodową, która wybuchła w reakcji na skorumpowane, autorytarne rządy?

Mit ten miał mieć także własnych herosów. W tej roli obsadzani byli z oczywistych względów Bakijewowie. Budowano pomniki, zmieniano nazwy ulic, publikowano książki i artykuły, organizowano konferencje naukowe, kręcono filmy, powstawały inscenizacje wydarzeń. Wszystko to miało utrwalić pożądaną pamięć społeczną i zepchnąć w zapomnienie to, co niefunkcjonalne dla władzy. Jednym z ostatnich działań prezydenta Bakijewa na rzecz upamiętniania rewolucji tulipanowej było przygotowanie projektu ustawy o ogłoszeniu

Dr Nartsiss SHUKURALIEVA jest adiunktem w Kujawsko-Pomorskiej Szkole Wyższej w Bydgoszczy. nartsiss7@mail.ru

\section{-.....}

Np. К. Исаев, 2005-жыл Кырәызстандын кайра жаралуусунун башаты, Бишкек 2005; Т. Кененсариев, Опыт демократии в Кырәызстане: история, реалии и перспективы, w: Опыт демократических ресрорм на Евразийском пространстве: сравнительные модели и практические механизмы. Еуразиялық кеңістіктеаі демократиялық реформалардың тәжірибесі: салыстырмалы үлгілері мен қолданбалы тетіктері, red. А.М. Байменов, Б.К. Султанов, Алматы 2006. 
amnestii w stosunku do osób, które aktywnie uczestnicząc w rewolucji marcowej w 2005 roku, popełniły przestępstwa z premedytacją, z wykluczeniem ciężkich przestępstw². Ustawa nie zdążyła jednak wejść w życie. Dwa tygodnie po hucznie obchodzonych w 2010 roku uroczystościach jubileuszowych prezydent został obalony wskutek kolejnych dramatycznych wydarzeń, określanych mianem rewolucji kwietniowej.

W niniejszej pracy analizowane są wystąpienia, wywiady, komentarze, publikacje Bakijewów i ich ideologów w latach 2005-2010. Zostały one potraktowane jako elementy współtworzące oficjalną pamięć. Pytania związane z próbą konstruowania przeszłości i oficjalnej pamięci o rewolucji z 2005 roku dotyczyły kilku kwestii. Jaka była relacja między rządami rodzinnymi a rewizją przeszłości? Jakie wątki w upamiętnianiu czasów przedi porewolucyjnych były wspólne dla Bakijewów? Jaką narrację budowała rodzina o samej sobie, ustami i piórem swoim oraz swoich ideologów? Czy K. Bakijew jako głowa państwa zajmował wyróżnioną pozycję? W jaki sposób interpretował on wydarzenia marcowe?

\section{WŁADZA RODZINY A GLORYFIKUJĄCA PRZESZŁOŚĆ}

Uprzywilejowaną pozycję w konstruowaniu i dystrybucji pamięci o przeszłości miała rodzina Bakijewów. Zajmowali oni wysokie stanowiska państwowe, dominując również w sferze układów nieformalnych. Dość liczna, nawet jak na kirgiskie warunki, obejmowała ona sześciu braci prezydenta. Dżusupbek (ur. 1951) był zastępcą dyrektora Agencji Rozwoju i Inwestycji Wspólnot. Kanybek (ur. 1956) był głową rządu wiejskiego (odpowiednik sołtysa) Yrys oraz gospodarstwa rolniczego "Tejit”. Brata Dżanybeka (ur. 1958) prezydent podniósł do stopnia generał lejtnanta; był szefem Służby Ochrony Państwowej, w praktyce sprawował kontrolę nad wszystkimi resortami siłowymi w kraju. Akmatbek (ur. 1960), prezes firmy "Saly-Ata" (z kirgiskiego „Ojciec Saly"), znany był jako nieformalny wojewoda obwodu Dżalalabad. Miał tu prawie bezgraniczną władzę, „kontrolował wszystko i wszystkich"3. Adylbek (ur. 1961) był doradcą ministra spraw zagranicznych oraz przewodniczył narodowej federacji Karate-do. Najmłodszy, Maratbek (ur. 1963), natychmiast po zmianie władzy został ambasadorem Kirgistanu w Niemczech.

Do rządzącego klanu należeli także przynajmniej dwaj dorośli synowie prezydenta z oficjalnego małżeństwa z Rosjanką Tatianą Bakijewą ${ }^{4}$. Marat służył jako zastępca ${ }^{5}$ prezesa Komitetu Bezpieczeństwa Narodowego. Rozszerzając swoje wpływy we wszystkich resortach siłowych, wpływał na ograniczanie znaczenia swego wujka. Rozszerzaniu pajęczyny rodzinnych układów we wszystkich strukturach państwowych towarzyszyło wzmacnianie polityczno-ekonomicznej potęgi młodszego syna prezydenta, Maksima.

\section{......}

2 Patrz: Президент намерен объявить амнистию к 5-летию мартовской революции, „АКИрress” 23.03.2010.

3 О. Жук, 8 эпизодов из жизни Ахмата Бакиева, "ДелоN" 03.12.2010.

4 Prezydent miał również dzieci z innych związków, jednak ustalenie ich wpływu na bieżącą polityke jest kwestią niezmiernie trudną, zważywszy na niejawny charakter takich działań. Ostatni związek K. Bakijewa, w którym miał dwójkę niepełnoletnich dzieci, został oficjalnie ujawniony dopiero po wydarzeniach kwietniowych 2010 r. Udzielając poparcia obalonemu prezydentowi Kirgistanu, fakt ów upublicznił prezydent Białorusi Aleksandr Łukaszenko. Patrz: Лукашенко готов принять Бакиева. Его свергли в том числе „Россия с Казахстаном", http://www.newsru.com/world/18apr2010/lb.html, 18.04.2010.

5 Z powodu braku ekwiwalentnego stowa w języku polskim, które trafnie oddawałoby stanowisko zajmowane przez syna prezydenta Bakijewa, Marata, użyto pojęcia „zastępca”. Stanowisko dżardamczy (z ros. помощник, z kirg. жардамчы) tłumaczone jest zwykle jako zastępca lub doradca. Jednak oba te słowa „zastępca" (czyli орун басар z kirgiskiego lub заместитель z rosyjskiego), czy „doradca” (czyli кеңешчи z kirgiskiego lub советник z rosyjskiego) w realiach Kirgistanu oznaczają zbliżone, niemniej jednak różne stanowiska w hierarchii urzędniczej. 
Trzydziestoparoletni Maksim miał jednak ambitniejsze plany niż tylko pomnażanie swego majątku. Szefował rządowej Agencji Rozwoju, Inwestycji i Innowacji, kontrolującej środki finansowe napływające do kraju z zagranicy. Powołując samodzielny gabinet, dość szybko stał się de facto drugim człowiekiem w państwie. Co więcej, to on namaszczony był na tego, kto miał rządzić krajem w przyszłości. Urzeczywistnianiu tej wizji sprzyjać miały krążące w obozie prezydenckim pomysły przekazania władzy synowi, w sytuacji gdyby K. Bakijew nie mógłby pełnić swoich obowiązków ${ }^{6}$.

Na szczycie tej hierarchii stał prezydent. Jego pozycja w systemie politycznym, podobnie jak i całego klanu, naruszała zasadę trójpodziału władzy. Był on ponad parlamentem, rządem i władzą sądowniczą. Centralizacja władzy, obszerne uprawnienia połączone z brakiem instytucjonalnej odpowiedzialności czyniły z niego główny podmiot odpowiedzialny za upamiętnianie. Prezydenckie dekrety, wywiady, wystąpienia, przemówienia oraz publikacje wyznaczały kierunki działania innych, szerzej oddziałujących kanałów komunikowania. Miały one „jak kompas wskazywać droge” urzędnikom realizującym projektowane idee ${ }^{7}$. Treść przekazu była jednak pełna sprzeczności. W opisywaniu rewolucji tulipanowej oraz wydarzeń ją poprzedzających przemawiał on wieloma głosami i podtrzymywał różne pozycje. Wspierały się one na dychotomii wartości demokratycznych i autorytarnych. Jako głowa państwa pozycjonował swą politykę jako nowy demokratyczny początek, ale i jako kontynuację autorytarnej przeszłości.

W odróżnieniu od prezydenta rodzina zajmowała jednoznaczną pozycję. Propagowana przez nią wersja dyskursu nie zależała od bieżących oczekiwań aktorów międzynarodowych i krajowych. W utrwalaniu rzeczywistości i przekształcaniu przeszłości krewni korzystali z większych swobód. Stąd brak było napięcia między wersją demokratyczną a autorytarną dyskursu, charakterystycznego dla wypowiedzi K. Bakijewa. Obficie korzystali oni z argumentacji autorytarnej, nieskrepowanie sami siebie czyniąc bohaterami, zmieniając nazewnictwo ulic, a nawet stawiając pomniki. Ich dyskurs był całkowicie pozbawiony demokratycznego składnika. Zgodnie z tą linią udzielane były wywiady, pisano artykuły, powstawały książki i filmy. Za pośrednictwem szeregu rodzinnych fundacji finansowali oni także rozmaite przedsięwzięcia kulturalne, które budować miały wizerunek hojnych filantropów (np. sponsoring sportowców czy wspieranie uzdolnionych studentów lub muzyków). Wszystko to miało potwierdzać rządową politykę oraz dominującą pozycję Bakijewów. W ten sposób konstruowany dyskurs wykorzystywany był przez urzędników państwowych, prorządowych dziennikarzy i polityków. Z jednej strony, dodatkowo wzmacniało to wysitki prezydenta, intensyfikując działania legitymizacyjne. Z drugiej natomiast wprowadzało element rodzinnego pluralizmu, który miał znaczenie dla interpretacji zarówno dawnych czasów, jak i wydarzeń marcowych. Podział na braci oraz synów, a wraz z nim - bardziej skomplikowany, zasilany konkretnymi interesami politycznymi - układ wyobrażeń na temat przeszłości, częściowo tylko pokrywał się z wersją, którą kształtował prezydent. W ten sposób pluralizm rodzinny znajdował swoje odzwierciedlenie w pluralizmie interpretacji najnowszej historii Kirgistanu.

Mimo powyższego wewnętrznego konfliktu (ambiwalencja dyskursu K. Bakijewa a autorytaryzm krewnych), w przekazach istniała jednak pewna dominująca nuta. Wyrażała się

\section{- ・. •}

W trakcie rządów K. Bakijewa o decyzjach politycznych mających przygotowywać grunt pod przekazanie władzy synowi (co przypominałoby casus Azerbejdżanu) głosili głównie opozycyjni politycy i media. Jednak wkrótce po odejściu ze stanowiska K. Bakijew niejednokrotnie potwierdzał tę tezę. Рatrz np. К. Бакиев, Я сегодня не вмешиваюсь ни прямо, ни косвенно во все то, что происходит в Кыргзыстане, „РИА Новости" 24.05.2010.

7 Wywiad z prokuratorem rejonu Alamudun, patrz: А. Бакачиев, Адам укугу баарынан бийик, Маектешкен А. Макешова, „Эркин Тоо” 21.11.2008, N88 (1802), s. 9. 
ona chociażby w książkach Dżumakana Sarijewa „Obowiązek wobec ojczyzny. Na ścieżce rozwoju. Prezydent Kurmanbek Bakijew"8, Sabyrżana Dżoldoszewa i Saparbeka Tokojewa „Potomkowie Tejitchana"9 oraz "Rejon Suzak: Czasy i postacie”10, które hagiograficznie opowiadały o historii rodziny Bakijewów. W reinterpretacji przeszłości dokonywanej we wskazanych tytułach dużą rolę odegrała formalizacja neotrybalizmu i regionalizmu. Zgodnie z nią naród kirgiski był rozpatrywany nie jako jednolita całość, lecz sfragmentaryzowany twór. Czasy przedkomunistyczne opisywano z perspektywy podziałów plemiennych. Co ciekawe, stosunkowo egalitarna struktura społeczna przez ideologów reżimu przekształcała się w twór mocno hierarchiczny. Na jej szczycie miało bowiem stać plemię (Aryk) Tejit, z którego pochodziła rodzina prezydencka. Dla wzmocnienia tej tezy miały być prowadzone dalsze badania ${ }^{11}$. Według Kurbanali Azimowa, Tejit będąc w grupie plemiennej Ichkilik, był nie tylko jednym z "najdawniejszych plemion” ${ }^{2}$, ale także był on „fundamentem powstania narodu Kirgiskiego"13. Co więcej, materiały historyczne świadczyć miały, że z Tejit pochodziło aż jedenastu chanów. Zgodnie z tym wyliczeniem ostatnim przywódcą, czyli jedenastym chanem, był sam prezydent Kurmanbek Bakijew ${ }^{14}$. Na dodatek przodkiem głowy państwa miał być (noszący to samo imię) XVI-XVII-wieczny epicki baatyr (z kirgiskiego „bohater") Kurmanbek, który heroicznie walczył o wolność i niezawisłość Kirgizów. Powyższe argumenty szły w parze z wchodzącym wówczas do obiegu publicznego terminem „adżo" (z kirgiskiego „wódz”, „przywódca”, „,bohater”), używanym dla nieformalnego określenia prezydenta ${ }^{15}$. Termin ten został dość szybko przyjęty przez media, posługiwali się nim także politycy, inteligencja, zwykli ludzi, a nawet przeciwnicy systemu.
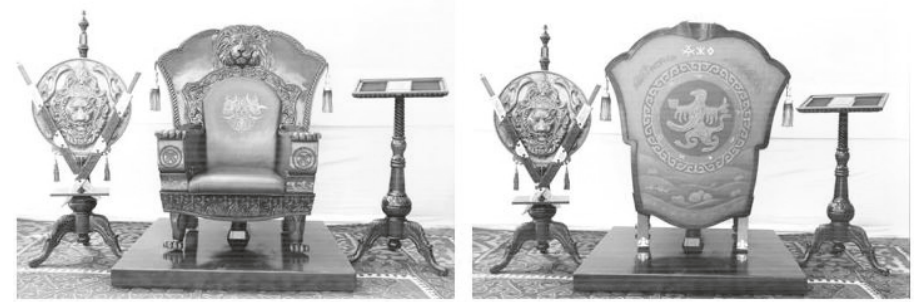

Tron Kurmanbeka Bakijewa. Wedle dyrektora ośrodka analitycznego Religia, prawo i polityka, Kadyra Malikowa, znaleziony w rezydencji rodziny Bakijewów w Dżalalabadzie w maju 2010 r. Siedzisko miało pełnić funkcję tronu kirgiskiego chana. Świadczyć o tym miało obfite czerpanie z symboliki chańskiej oraz napis „Adżo” na tylnej ścianie oparcia siedziska, imitujący pismo runiczne.

Źr ó d †o: К. Маликов, Бакиеву готовили ханский трон, „ДелоN” 06.05.2010.

-....

8 Ж. Сариев, Ата Журт алдындагы парз. Мезгил арымдары... Президент Курманбек Бакиев. Даректуу баян, Бишкек 2009.

9 С.Н. Жолдошев, С.И. Токоев, Тейитхандын урпактары, Бишкек 2010.

10 Сузак району: мезаил жана инсандар, Башкы ред. О. Каратаев, түзүүчүлөр С. Стамбеков, А. Акжолов, М. Аширбаев, Бишкек 2009.

11 Np. С.Н. Жолдошев, С.И. Токоев, ор. cit.; Ж. Сариев, ор. cit.

12 Ж. Сариев, op. cit., s. 22.

13 Ibidem.

14 Ibidem, s. 23

15 Nie ma jednolitej opinii wśród badaczy co do pierwotnego znaczenia słowa "adżo". Po raz pierwszy pojawia się ono w źródłach jako tytuł przywódcy Kirgizów z VIII wieku. Podczas gdy rosyjski naukowiec Nikita Jakowlewicz Biczurin (XVIII-XIX w.) interpretował słowo „adżo” jako monarcha Kirgizów, to znawca kirgiskiej genealogii (z kirg. санжырачы) Turdakun Sultanov był odmiennego zdania. Według niego, „adżo” u Kirgizów oznaczało nie przywódcę, lecz bohatera. W czasach rządów Bakijewa termin „adżo” w prasie był niekiedy wykorzystywany jako kirgiski ekwiwalent słowa „prezydent”. Patrz np.: Т. Султанов, Кырәыздардын өзөктуу санжырасы, Бишкек 2010, s. 101; Н.Я. Бичурин, Собрание сведений о народах, обитавших в Средней Азии в древние времена, t. 1, Москва-Ленинград 1950, s. 352. 
Wykres 1. Lista kirgiskich chanów pochodzących z plemienia Tejit według Kurbanali Azimowa

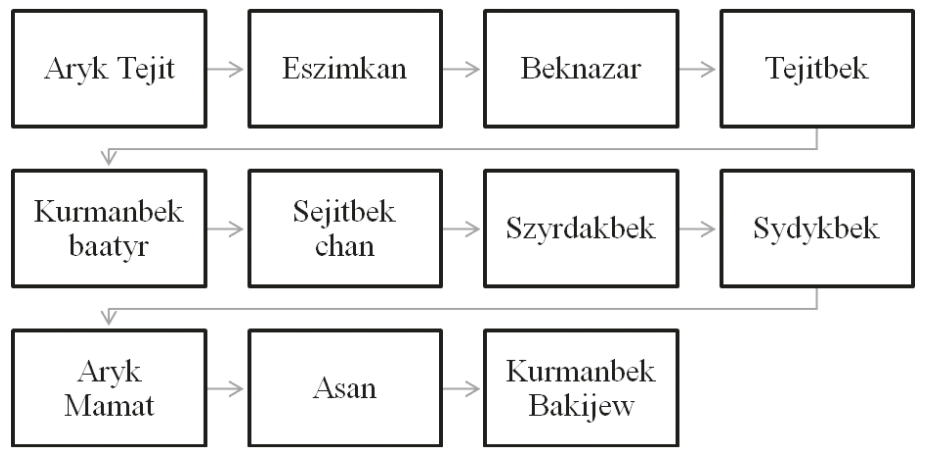

Źr ó d ło: Opracowanie własne na podstawie Ж. Сариев, op. cit., s. 19-24.

Podobnej rekonstrukcji uległy także czasy radzieckie. Nie ma tam mowy o walce klasowej czy chociażby wzmianki o represjach. Egalitarna idea komunizmu została i tutaj zastąpiona hierarchią. Wyodrębnia ona z całej republiki obwód Dżalalabad, a w nim rejon Suzak, z kolei dalszą, a potem bliższą rodzinę. Ojciec prezydenta, Saly, funkcjonariusz NKWD, a później KGB, który „krótko trzymał funkcjonariuszy służby bezpieczeństwa”16, był tu wynoszony do rangi bohatera. Był też liderem długiej listy wybitnych postaci, które pochodziły z prezydenckiej grupy plemiennej albo regionu. Wszyscy mieli wiernie pracować i z oddaniem walczyć ku chwale ojczyzny ${ }^{17}$. Generalnie, czasy komunistyczne wspominane były jako okres bezpieczeństwa socjalnego i dobrobytu. Sytuacja w kraju jest ściśle wiązana z pozycją Bakijewów, bo to oni w owym czasie mieli zajmować centralne miejsce i kierownicze stanowiska, rzekomo przyczyniając się tym samym do jego prosperity ${ }^{18}$. Ten mechanizm gloryfikacji przez skuteczność i efektywność był wielokrotnie eksploatowany.

Wskazane mechanizmy wykorzystywane były także dla legitymizującej Bakijewów reprezentacji czasów niepodległości. Okres ów miał ważne znaczenie dla narracji, bo wtedy wydarzyła się rewolucja, której wizja stanowiła oś dyskursu prezydenckiego. Rewolucja marcowa jako okres poprzedzający miała kluczowe znaczenie nie tylko dla wyjaśniania zmiany władzy z Akajewowskiej na Bakijewowską, ale także dla legalizacji reżimu jako całości. Demonizowano więc okres prezydentury Askara Akajewa, aby usprawiedliwić jego gwałtowne usunięcie. Tulipanowa rewolucja miała stanowić nowy początek dziejów. W ten oto sposób teraźniejszość i interesy ludzi, którzy tą teraźniejszością rządzili, wywierały ogromny wpływ na kształt pamięci przeszłości. Przeszłość z kolei stawała się integralną częścią teraźniejszości i oddziaływała na współczesność z nie mniejszą siłą ${ }^{19}$.

\section{$\cdots \cdots$}

16 Ө. Төлөбеков, Революцияга арналган өмүр же биртууган Бакиевдер (Даркетүу көркөм баян), Бишкек 2007, s. 17.

17 Np. imieniem Abdywasyta Bakijewa (wujka prezydenta) oraz Saly Bakijewa (ojca) zostały nazwane ulice. Przyznawano stypendium za osiągnięcia w nauce imienia Gulnary Bakijewej (kuzynka).

18 М. Шади уулу, Президент К. Бакиев - ноокаттык, „Аалам” 23.04.2009, s. 8.

19 E. Florescano, Od historii - pomnika władzy do historii wyjaśniającej, w: Po co nam historia?, tłum. M. Mróz, wstęp T. Łepkowski, Warszawa 1985, s. 71-72, 78. 
Wykres 2. Hierarchia plemienna według Kurbanali Azimowa

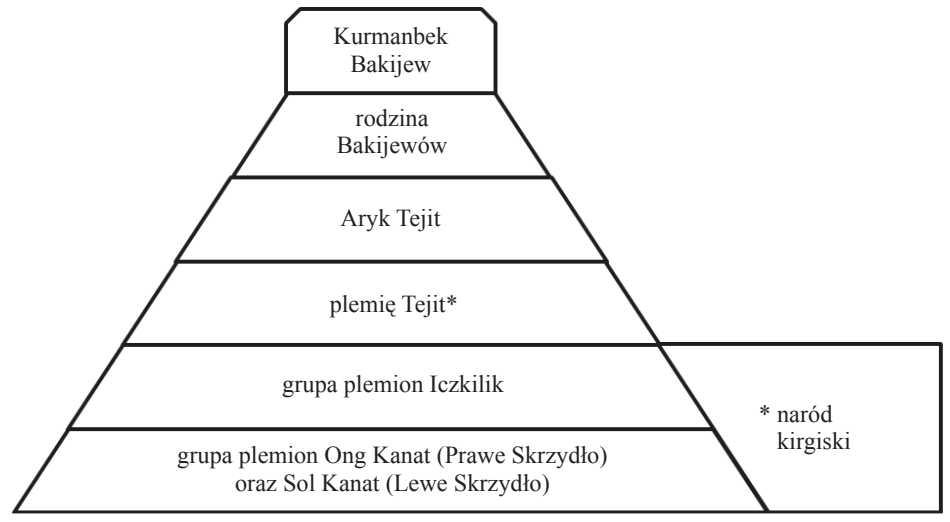

* Plemię Tejit składało się z dwunastu rodów: Aryk Tejit, Kara Tejit, Sary Tejit, Baj Tejit, Tokum Tejit, Ujgur Tejit, Czal Tejit, Dżaman Tejit, Czapan Tejit, Koczkor Tejit, Czygyrczak Tejit, Ajtemir Tejit.

Źródło: Opracowanie własne na podstawie Ж. Сариев, оp. cit., s. 19-24; С.Н. Жолдошев, С.И. Токоев, op. cit., s. 137.

\section{AUTOLEGITYMIZACYJNE ZABIEGI RODZINY BAKIJEWÓW}

Wydarzenia marcowe, w efekcie których K. Bakijew doszedł do władzy, wymagały, choćby słabego, ideologicznego uzasadnienia. W warunkach trwałej dewaluacji instytucji formalno-prawnych znaczenie legalizacji władzy było trudne do przecenienia. Choć na poziomie instytucjonalnym nowa władza niechętna była naruszaniu ciągłości, w przestrzeni symbolicznej retoryka odnowy i nowego początku odgrywała istotną rolę. Pamięć o rewolucji miała pełnić rolę poznawczego, emocjonalnego, normatywnego, prawnego, moralnego i instytucjonalnego uzasadnienia władczych roszczeń Bakijewów ${ }^{20}$. Nie miało tu jednak znaczenia, co naprawdę wydarzyło się w 2005 roku. Nieobecność zjawisk, które można by uznać za rewolucję nie przeszkadzała w upamiętnianiu przeszłości jako rewolucyjnej. W przestrzeni politycznej liczy się bowiem przede wszystkim to, jaki użytek można czerpać z pamięci. W tym sensie przeszłość jest przede wszystkim tworem teraźniejszości ${ }^{21}$.

Rewolucja marcowa miała dać Kirgizom nowych herosów. Jak wielokrotnie wskazywano, do roli tej pretendowali Bakijewowie. Ich wizerunek jako bohaterów stawał się wyraźniejszy wraz z neutralizacją opozycji i ograniczaniem pluralizmu. Mechanizm heroizacji widać wyraźnie chociażby w książce Omurbeka Tolobekowa "Życie poświęcone rewolucji a bracia Bakijewowie"22. Liczne zdjęcia archiwalne przeplatały się w niej z niemal mityczno-epicką opowieścią o bohaterstwie członków rodziny.

W centrum zawłaszczonej pamięci rewolucji stał brat prezydenta Dżusupbek Bakijew, który rok po wydarzeniach marcowych zmarł z powodu choroby serca. Jasno wyraża to napis na jego nagrobku, sławiący go jako człowieka, który "dla narodu poświęcił Swe ser-

\section{-....}

20 M. Ziółkowski, Przemiany interesów i wartości spoteczeństwa polskiego, Poznań 2000, s. 92, 105.

21 A. Szpociński, P.T. Kwiatkowski, Przeszłość jako przedmiot przekazu, Warszawa 2006.

22 ө. Төлөбеков, op. cit., s. 8, 12. 
ce, dla Ojczyzny oddał Swe życie" 23 . Sformułowanie to było konsekwentnie powielane w przestrzeni zarówno publicznej, jak i prywatnej. W ten sposób dla szerokiego grona odbiorców Dżusupbek stawał się „,jednym z organizatorów i przywódców wystąpienia narodu przeciwko niesprawiedliwości poprzedniej władzy"24. Zabieg ten dobrze pokazywał mechanizm personalizacji wydarzeń rewolucyjnych: jedna osoba (zawsze związana z rodziną Bakijewów) uosabiała wolę i wysiłek całej stojącej za wydarzeniami zbiorowości. Związek pomiędzy śmiercią brata a pamięcią rewolucyjną budowano poprzez odwołanie do powszechnego w Kirgistanie kultu przodków i zmarłych ${ }^{25}$. Na jego cześć nazwano szkołę, park, ulicę, wzniesiono pomnik oraz otwarto muzeum. Powstała również fundacja im. Dżusupbeka Bakijewa, której twórcą i prezesem był kolejny wpływowy brat prezydenta, Dżanybek.

Sakralizacja Dżusupbeka była kluczowym zabiegiem na rzecz rządzącej familii. Zabieg ów wzmacniało ustanowienie, z inicjatywy prezydenta, dnia 24 marca świętem narodowym oraz organizowanie rozmaitych uroczystości z nim związanych. Prywatyzując święto, rodzina określała mniej od siebie znaczących bohaterów rewolucji. Obchody świąteczne, w trakcie których miały miejsce przemowy władz lokalnych, występy piosenkarzy, tancerzy, aktorów, zawody sportowe, przekształcały się w hołd składany heroizmowi klanu rządzącego.

„W wyniku przemian ponownie pojawiła się nadzieja na władzę, która teraz zaczęła służyć ludowi"26, twierdził gubernator obwodu Batken, Ajtibaj Tagajew, jeszcze dwa tygodnie przed obaleniem władzy wiosną 2010 roku.

Heroizujący przekaz obchodów należał do zabiegów narracyjnych, które dostarczały wzorów reprezentacji Bakijewów. Część książek korzystających z tego sposobu budowania opowieści była ich własnego autorstwa. Na przykład w książce "Rewolucja marcowa: historyczny wybór narodu"27 prezydent poświęcił szczególną uwagę gronu bliskich mu ludzi. Narracja ta, współgrając z tworzonym przez rodzinę dyskursem, pozycjonowała własną rodzinę na biegunie przeciwnym względem powszechnie krytykowanej rodziny Akajewa. „Uzurpacja władzy przez jednego człowieka, jedną rodzinę oraz ich otoczenie, którzy stawiali swoje egoistyczne cele ponad interesami ludu i kraju doprowadziła w końcu do wydarzeń marcowych w 2005 roku. To ciężka nauczka dla nas wszystkich"28, twierdził Kurmanbek w 2005 roku. Zdecydowana krytyka nepotyzmu swych poprzedników wiodła do czterech sposobów reprezentacji własnej familii.

Po pierwsze, autoprezentacja poprzez cechy osobiste. Bakijewowie od rodziców po wnuki kumulować mieli pozytywne cechy osobiste. W kreowaniu ich wizerunku hojnie czerpano z kirgiskiej tradycji epickiej. Wykorzystywano wyobrażenia z ludowego folkloru. Odwołując się do przeszłości, byli oni jednak bohaterami dzisiejszych czasów. Mieli kontynuować dzieło najwybitniejszych postaci kirgiskiej historii. W niczym nie gorsi, lecz przeciwnie, równie wielcy i szlachetni. Mieli być szczerzy, uczciwi, dobrzy, dobroduszni, pracowici, „żyli za samą pensję" 29 oraz ubolewali nad niedolą kraju i jego obywateli30.

\section{......}

23 Napisy z nagrobka Dżusupbeka Bakijewa (18.09.1951 - 21.02.2006). Wersja oryginalna: „Элим деп жүрөгүңдү арнап кеттиң, жерим деп өмүрүңдү сайып кеттиң [...]".

24 Cytat za: Вышла в свет книга „24 марта 2005 года - Народная революция”, „Кабар” 22.03.2006.

25 J. Le Goff, Historia i pamięć, tłum. A. Gronowska, J. Stryjczyk, Warszawa 2007, s. 126.

26 А.Тагаев, Народная революция вернула доверие и надежду народа, „АКИpress-Фергана” 24.03.2010.

27 К. Бакиев, Мартовская революция: исторический выбор народа, Бишкек 2010.

28 К. Бакиев, О национальной стратегии развития и ближайших задачах. Послание Президента КР К. Бакиева народу Кыргызстана, „МСН” 29.09.2006.

29 Co oznaczać miało ich pracowitość, uczciwość, nieprzekupność oraz gotowość do skromnego życia wytącznie z oficjalnie uzyskiwanych dochodów. К. Бакиев, Эл үчүн күйгөн ишмер эле..., Маектешкен Ө. Төлөбеков, w: Ө. Төлөбеков, ор. cit., s. 6.

30 К. Бакиев, Возврата к прежним порядкам не будет, „Общественный рейтинг” 29.12.2005; Стенограмма ответов Президента КР К. Бакиева на вопросы на русском языке во время прямого эфира по ГТРК 
Po drugie, autoprezentacja poprzez czyny. Byli oni przedstawiani jako bohaterowie rewolucji. Nie mogli z obojętnością patrzeć na rażącą niesprawiedliwość. Mieli również stawać opór autorytarnemu reżimowi. „I to, że wielotysięczne mityngi przeszły bez poważnych ekscesów - to wielka zasługa Dżusupa Bakijewa" ${ }^{31}$. Liczna rodzina przedstawiana była jako bardzo dobrze zorganizowana, samodzielna instytucja, która obok Narodowego Ruchu Kirgistanu była motorem protestów społecznych przeciwko skorumpowanym rządom.

Po trzecie, autoprezentacja poprzez sytuowanie siebie w roli ofiary. Bakijewowie byli także przedstawiani jako ofiary, czy nawet organicystycznie - męczennicy rewolucji. Poszczególni członkowie rodziny, a także rodzina jako całość byli szczegółowo opisywani. Opowiadano rozmaite, rozbudowane często historie prześladowań: „[...] cała nasza rodzina była poddawana masowemu naciskowi ze strony władzy"32. "Widząc oburzającą bezkarność władzy, Dżanysz włączył się w walkę o sprawiedliwość. Ponownie za to cierpiał" 33 . Największe znaczenie miała postać brata Dżusupa. Jego śmierć była momentem kulminacyjnym, świadczącym o szczerych intencjach wobec losu ludu i kraju. Była interpretowana jako ofiara, którą poniosła rodzina Bakijewów w walce o sprawiedliwość.

Czwarty sposób autoprezentacji polegat na ustanawianiu szczególnej, w swej istocie populistycznej, relacji z ludem. Zamiarem było tu nie tylko pokazanie, że Bakijewowie pochodzili z ludu, ale że równocześnie byli ponad nim. Poczynając od ojca, członkowie rodziny opisywani byli jako osoby pełniące wysokie funkcje już od czasów radzieckich. „Wszyscy, każdy własną drogą, przeszli ważną szkołę życia. Mając doświadczenie na stanowiskach kierowniczych, są pożądanymi pracownikami"34. Opis ten, tak jak i poprzednie, odwołując się do przeszłości, miał rozwiązać kwestie teraźniejszości. Ich obecność na kluczowych stanowiskach postrewolucyjnego Kirgistanu była normalizowana poprzez takie sformułowania. Wysoka pozycja to naturalny atrybut członków rodziny, od zawsze określający ich biografie. Nieuzasadnione miały być stąd obawy o powrót rządów klanowych oraz uzurpację władzy. Prezydent odpierał te ataki. Jak twierdził, w odróżnieniu od Akajewa, jego rodzina „nigdy nie wtrącała się w sprawy państwowe, do polityki kadrowej"35. Każdy miał być samodzielny, nie tylko nie potrzebował wsparcia prezydenta, ale jednocześnie „nikt z nich nie mógł na niego [prezydenta - N. S.] wpłynąć" ${ }^{36}$. Inna argumentacja zakładała, że związki rodzinne z prezydentem nie są wystarczającym powodem dla rezygnacji z kariery zawodowej. Wręcz przeciwnie, powierzenie członkom rodziny wysokich stanowisk było przedstawiane jako całkowicie zgodne z interesem narodowym. Osobiste ich przymioty, jak uczciwość, sumienność oraz profesjonalizm, gwarantować miały oddanie w pracy na rzecz ludu i państwa.

Heroizacja oraz gloryfikacja K. Bakijewa oraz członków jego rodziny pociągała za sobą pewną wizję struktury społecznej, jej znaczenia oraz roli w obaleniu niesprawiedliwych rządów. W tej retorycznej wizji stratyfikacji społecznej poszczególne warstwy układają się hierarchicznie i składają z podmiotów indywidualnych oraz zbiorowych. Z analizy materiatów empirycznych wynika, że na szczycie piramidy społecznej znajdował się prezydent, jego zmarły brat, dalej zaś cała rodzina Bakijewów. Rejon Suzak, obwód Dżalalabad oraz południe Kirigistanu wyznaczały kolejne warstwy mierzone stopniem odległości od pre-

20.12.2006, http://www.president.kg/press/vistup/1844/ 25.07.2009

К. Бакиев, Мартовская..., s. 63.

32 Ibidem, s. 61

33 Ibidem, s. 62

34 К. Бакиев, Приоритетов не меняю. Беседовали Д. Евлашков, П. Негоица, „Российская газета” 27.01.2006, Федеральный выпуск nr 3982.

35 К. Бакиев, Возврата...

36 Ibidem. 
stiżu i rewolucyjnej chwały. W ten sposób pochodzenie panującej rodziny uprzywilejowywało południowe klany, względem całej populacji Kirgistanu. Korespondowało to z mitem obalenia władzy przez południowych Kirgizów, z czego wywodzono prawo do uprzywilejowanej pozycji w strukturach władzy.

Wykres 3. Oficjalna hierarchia bohaterów rewolucji

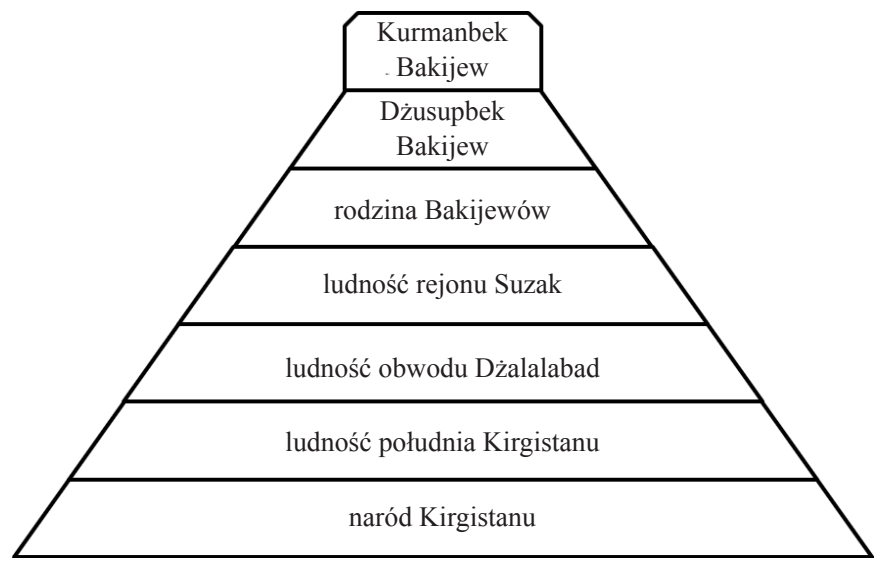

Źródło: Opracowanie własne.

Im mniej demokratyczne było państwo, tym bardziej rosło znaczenie Bakijewa i jego rodziny. Aktywna obecność klanu rządzącego oraz krzewionej przezeń pamięci rewolucyjnej miały wzmacniać symboliczne podstawy rzeczywistości, w której nie tylko prezydent, ale również jego otoczenie miało dostęp do ograniczonych zasobów. Zabiegi interpretacyjne uprawomocniały porządek, w którym de facto zajmowali oni nadrzędną pozycję ponad prawem, ponad instytucjami państwowymi, a niekiedy nawet nad cudzą własnością prywatną. Szykanowano opozycję oraz sprzyjającą jej elitę symboliczną. Ograniczano wolność słowa i prasy. Jednocześnie zachęcano do podtrzymywania oficjalnie tworzonej rzeczywistości symbolicznej. W ten oto sposób władza ustalała hierarchię spraw ważnych i nieważnych, określając, co ma być pamiętane, a co ma ulec zapomnieniu. Wszystkie wskazane zabiegi nie były jedynie tworzeniem fasady, która nie ma wpływu na sposób myślenia ludzi. Należy je raczej postrzegać jako celowy wysiłek, by Bakijewowska wersja wydarzeń stała się częścią społecznie podzielanych przekonań, tak aby ci, którzy w nią uwierzyli, dzięki jej przyswojeniu, stawali się lojalną wspólnotą wyobrażoną ${ }^{37}$.

REPREZENTACJA REWOLUCJI W WYPOWIEDZIACH BAKIJEWA

W ciągu pięcioletnich rządów K. Bakijewa tematyka rewolucyjna czy, szerzej, odwoływanie się do wydarzeń marcowych było stałym elementem prezydenckich wystąpień, wywiadów, komentarzy i publikacji. Mimo to nie wypracowano spójnej ideologii ani jednego

\footnotetext{
37 B. Szacka, Czas przeszły pamięć i mit, Warszawa 2006, s. 54-58; B. Anderson, Wspólnoty wyobrażone: rozważania o źródłach i rozprzestrzenianiu się nacjonalizmu, tłum. S. Amsterdamski, Kraków 1997, s. 153-159.
} 
stanowiska wobec rewolucji. Jedyną koherentną, doprecyzowaną wizję dawała książka K. Bakijewa z 2010 roku pt. „Rewolucja marcowa: historyczny wybór narodu”. Odcinając się od poprzednio stawianych tez, autor formutował w niej całkowicie nowe spojrzenie na rewolucję, lud oraz państwo. Wydana na pięciolecie rewolucji, miała stworzyć początek nowej formy upamiętniania rewolucji, a za jej pośrednictwem nowe mechanizmy sprawowania władzy. Tekst miał być rdzeniem ideologii władzy, która jednoznacznie opowiadała się za systemem autorytarnym. Miał on „pełnić rolę podręcznika dla polityków i urzędników wysokiego szczebla"38. Na jubileusz rewolucji w marcu 2010 roku książka z autografem prezydenta była więc rozdawana uczestnikom „Yntymak Kurultajy” (z kirg. Zjazd na rzecz Zgody) oraz wybranym przedstawicielom trzech gałęzi władzy. Jednak idea jednolitego stanowiska nie przetrwała nawet miesiąca. Odbiorcy zapewne nie zdążyli przeczytać opracowania, bo reżim upadł już w kwietniu 2010 roku.

Niezależnie od powyższego, upamiętnianie rewolucji w wypowiedziach publicznych prezydenta nie powinno być rozpatrywane jako długoterminowa i zaplanowana polityka. Tworzona dla legitymizacji władzy Bakijewów była ono raczej częścią strategii nieustannego manewrowania w niestabilnym środowisku. Współtworzyła strategię doraźnego reagowania na zmiany zachodzące zarówno w kraju, jak i w środowisku międzynarodowym $^{39}$. Ciągłe dopasowywanie się do sprzecznych oczekiwań otoczenia, przy chęci zachowania status quo, rodziło sprzeczne treści w formowanej przez prezydenta pamięci o rewolucji. Można w nich wyróżnić dwie, splatające się ze sobą narracje: demokratyczną oraz autorytarną. W reakcji na bieżącą sytuację wykorzystywano je zamiennie, reagując stosownie do zewnętrznych bodźców. Stosowano je również jednocześnie, gdy ambiwalentność przekazu mogła sprzyjać autolegitymizacji.

Geneza dysonansu demokratyczno-autorytarnej formy legitymizacji władzy leżała w niejednoznaczności wydarzeń marcowych. W tym, że za dyskredytacją rządu, przejęciem władzy przez nową grupę nie nastąpiły rewolucyjne zmiany instytucji politycznych, struktury społecznej, a także działalności i polityki rządu. Jednak mimo oficjalnego uznania formalnoprawnej sukcesji władzy, wydarzenia marcowe gruntownie zmieniły mentalność i postawy członków społeczeństwa. Wynikało to z mobilizacji obywatelskiej, wyrażającej się w czynnym lub biernym uczestnictwie przeważającej większości w protestach przeciwko rządom A. Akajewa bądź pasywnej niechęci. Ludzie z rejonów tradycyjnie uznawanych za prorządowe, w których zwykle władza uzyskiwała najwyższy odsetek głosów podczas wyborów i referendów, wyszli na ulice. Pogrążone w bierności i apatii grupy zaczęły się organizować. Władza została obalona. Doświadczenie to było przedmiotem wyjątkowego stanu emocjonalnego ${ }^{40}$.

Rewolucja, którą witano z entuzjazmem i nadzieją, ale także z lękiem i niepewnością, była dla wielu bezpośrednim i osobistym przeżyciem świeżo zachowanym we wspomnieniach. Okres żywej pamięci tych zajść był zbieżny z czasem prezydentury Bakijewa. Istnienie żywej pamięci uniemożliwiało władzom pełną kanonizację wydarzeń marcowych. Powstrzymywało również przed wykreślaniem z obrazów przeszłości jej demokratycznych pierwiastków. Wręcz przeciwnie, odwołując się do wolności, suwerenności ludu i odrodzonego państwa, władza konkurowała z żywą pamięcią. Z jednej strony próbowała dokonać w niej przekształceń, z drugiej natomiast wpisać się w jej kształt tak, by trudne

\section{-.....}

38 М. Залиханов, Предисловие, w: К. Бакиев, Мартовская.., s. 8.

39 A. Portnow, "Wielka Wojna Ojczyźniana" w polityce pamięci Białorusi, Mołdawii i Ukrainy, "Respublica nowa" jesień 2009, nr 7, s. 26.

40 H. Arendt, O rewolucji, ttum. M. Godyń, Warszawa 2003, s. 38; P. Sztompka, Socjologia, Kraków 2002, s. 28, 39; E. Matynia, Demokracja performatywna, tłum. M. Lavergne, Wrocław 2008, s. 11-17. 
było odróżnienie tego, co społeczne, od tego, co politycznie konstruowane. Ponadto władza usiłowała uzyskać hegemonię w korzystaniu z retoryki demokratycznej i uczynić z niej jeden z filarów legitymizacyjnych.

Pamięć o rewolucji budowana przez K. Bakijewa w swojej wersji demokratycznej nie prezentowała jednak wyrafinowanej koncepcji ze skomplikowaną i spójną konstrukcją myślową. Nie wychodziła poza obszar typowych klisz retorycznych. Prezydentowi były raczej bliższe narzędzia analityczne popularnych wyobrażeń o demokracji, charakterystyczne dla populistycznej formy uprawiania polityki. Podkreślał on więc suwerenność i sprawstwo woli ludu. Rewolucja miała być unikatowym momentem historii, w którym władza została przywrócona ludowi. Znaczenia nabierała więc kwestia początku i mit umowy społecznej ${ }^{41}$. Mit ten, eksponując zamiłowanie Kirgizów do wolności, opowiadał historię o tym, jak od wieków przeżywając momenty wzlotu i upadku, wytrwale walczyli oni przeciwko agresorom i tyranii. Pielęgnowana przez stulecia idea państwowości i wolności została zrealizowana, gdy suwerenny lud ustanowił własne państwo. Ten mit założycielski demokratycznego Kirgistanu był wcześniej stałym elementem retoryki A. Akajewa. Po drobnej korekcie (przesunięciu momentu przełomowego na rewolucję tulipanową) miał on zagościć również w rewolucyjnym dyskursie K. Bakijewa ${ }^{42}$. Za moment przełomowy, czas odnowy i początku, uznane zostały wydarzenia marcowe i dojście do władzy Bakijewa. W tej interpretacji lud odzyskiwał utraconą władzę i wolność, a zadaniem prezydenta było służyć ludowi. Co więcej, dyskurs przyznawał ludowi prawo oporu. W razie uzurpacji władzy przez nowych przywódców, suweren mógł powstać ponownie i przywrócić jej prawowitość ${ }^{3}$.

Pamięć o rewolucji tulipanowej kształtowanej przez K. Bakijewa miała jednak także drugie oblicze. W swojej autorytarnej wersji rewolucja nie była walką o wolność i wyzwolenie. Nie przywracała dawnych praw i swobód. Nie stawiała kwestii początku. Autorytarna narracja obrazów przeszłości przyczyny protestu obywatelskiego widziała nie tyle w politycznym sprzeciwie wobec ucisku, ile w braku realizacji podstawowych potrzeb socjalnych. Kluczową kwestią było więc nie tyle przeniesienie źródła prawa z osoby prezydenta na konstytucję, lecz rozwiązanie kwestii społecznych, takich jak np. likwidacja bezrobocia, zabezpieczenie wzrostu gospodarczego czy budowa dróg. Co więcej, rewolucja reprezentowana jako przemoc, lęk, i niepewność anulowała wątki mówiące o „zwycięstwie suwerennego ludu"44. Lud był porzucony, gdy pojawia się na arenie nowy pater,

\section{$\cdots \cdots$}

41 H. Arendt, op. cit.; P. Sztompka, op. cit., s. 30-31.

42 Nр. К. Бакиев, КР Президенттик кызматына киришүүдө сүйлөгөн сөз, 14.08.2005; К. Бакиев, Инагурационная речь Президента КР, 14.08.2005, „МСН” 16.08.2005; К. Бакиев, Телевизионное обращение по случаю 2-й годовщины Народной революции 24 марта 2005 года, 23.03.2007; К. Бакиев, Выступление на торжественном мероприятии, посвященном 24 марта - Дню Народной революции, 24.03.2007; К. Бакиев, БУУнун башкы ассаблеясынын жогорку деңгээлдеги пленардык жыйынында (БУУнун саммити) сүйлөгөн сөзү, 16.09.2005, кара: Кыргызстан: Элдик революция. 24 март 2005. Народная революция, түзгөндөр П.Ш. Казыбаев, Б.О. Орунбеков, Л.А. Рудь, Г. Асанова, К. Болотканов, Бишкек 2006, s. 89.

43 Elementy legitymizacyjne rządu A. Akajewa były wykorzystywane również przez nową władzę. Wyraźnie pokazuje to stwierdzenie ministra rozwoju ekonomicznego i handlu, Akylbeka Dżaparowa z 2009 r. Odtwarzając stanowisko K. Bakijewa, w wywiadzie dla gazety "Kyrgyz tuusu”, twierdził on, że "z rewolucji ludowej powinniśmy wyciągnąć polityczną naukę. Określiła ona co to jest demokracja, jakie są poglądy i pozycja narodu kirgiskiego. [...] Według naszej konstytucji lud jest źródłem władzy. Władza (A. Akajew - N.S.) zapomniała o tym lekceważąc lud i nie licząc się z jego potrzebami. Jeżeli nie będzie się myślało o narodzie, w pewien dzień nie patrząc na twoją władzę lud wygoni ci z Kirgistanu. Reasumując, taka jest nauka". Wizja suwerennego ludu była aktualna aż do czasów rewolucji kwietniowej roku 2010, kiedy na fali protestów społecznych prezydent K. Bakijew został usunięty ze stanowiska i opuścił Kirgistan. Patrz: А. Жапаров, Банкрот өлкөну кабыл алганбыз, „Кыргыз туусу” 23.03.2009, nr 21, s. 9; Т. Кененсариев, Основные исторические этапы развития суверенного Кыргызстана, tekst w zbiorach autorki, s. 9.

44 H. Arendt, op. cit.; P. Sztompka, op. cit., s. 69-113. 
Bakijew. Jego zadaniem było zaopiekowanie się tym osieroconym ludem. Taka konstrukcja wspomnień ułatwiała legitymizację autorytarnego modelu władzy. Zapewniała również uznanie legalności struktur i praw poprzedniego ustroju ${ }^{45}$.

\section{PODSUMOWANIE}

Zadaniem artykułu było przedstawienie mechanizmów konstruowania przeszłości przez prezydenta Kurmanbeka Bakijewa i jego rodzinę. Czasy przedkomunistyczne, komunistyczne, okres niepodległości oraz wydarzenia marcowe reprezentowane były jako jedna ciągłość i przekształcane w narrację opowiadającą o niemal mitycznym heroizmie Bakijewów. Ważną kwestią była również odpowiedź na pytanie, w jaki sposób mechanizmy upamiętniania rewolucji tulipanowej, czyli momentu ich dojścia do władzy, przyczyniały się do legitymizacji władzy.

Tekst usiłuje zidentyfikować główne wątki charakterystyczne dla publicznych wypowiedzi głowy państwa, członków jego rodziny, a także ideologów reżimu. Zadaniem było jednak nie tyle odtworzenie spójnej i zwartej struktury, przypominającej oficjalną ideologię. Chodziło raczej o wskazanie na napięcia i dysonanse znamionujące publiczne wypowiedzi na temat przeszłości, będące reakcją na zmieniający się kontekst międzynarodowy oraz wewnętrzne grupy odbiorców. Polityka nieustannego manewrowania owocowała demokratyczno - autorytarną ambiwalencją w opisywaniu rewolucji. Z jednej strony rewolucja była upamiętniana jako kulminacja umowy społecznej. Moment, który wyrażał demokratyczne potwierdzenie roli ludu, władzy i państwa. Z drugiej natomiast strony, pamięć o rewolucji była wykorzystywana do realizacji dążeń autorytarnych i zachowania status quo.

Analiza prowadzi do wniosków, że obrazy przeszłości i wydarzeń marcowych to twór złożony i wielowarstwowy. Tym niemniej w ogólnym zarysie dominowała klanowo-centryczna, hierarchiczna konstrukcja, zogniskowana na rządzącej rodzinie. Wskazane aspekty i mechanizmy reprezentacji przeszłości można więc także postrzegać w kontekście łączenia struktur formalnych i nieformalnych, gdzie to, co państwowe ściśle wiązało się z tym, co prywatne.

XI KHAN OF KYRGYZSTAN: KURMANBEK BAKIYEV, FAMILY RULE AND HEROIZATION OF THE PAST

\section{Summary}

The aim of the article is to highlight mechanisms of the construction of the national past. The precommunist and communist times, period of independence and the events of March 2005 were used to design the narration on the almost mythical heroism of current authorities and their predecessors. The paper also attempts to reveal strategies of legitimization through the commemoration of the Tulip revolution.

\section{-....}

$45 \mathrm{Np.} \mathrm{К.} \mathrm{Бакиев,} \mathrm{Заключительное} \mathrm{слово} \mathrm{на} \mathrm{расширенном} \mathrm{заседании} \mathrm{правительства,} \mathrm{14.02.2006,} \mathrm{w:}$ Кырәызстан..., s. 305-315; К. Бакиев, Выборы будут свободными, Беседовал А. Гладилов, „Вечерний Бишкек" 29.04.2005, nr 80 (8754). 
Additionally, it tries to reconstruct and critically comment upon main arguments used in public speeches by the head of state, by his family and ideologues of the regime. The aim, however, is not to present the coherent structure of official thinking similar to ideology. Ambiguities, inconsistencies and ad hoc reactions constituted very important part of the regime's official rhetoric. That is why the paper emphasizes strong tension between authoritarian and democratic strands of official discourse used accordingly to the ever-changing context in which Bakijev's regime operated.

Keywords: Central Asia, Kyrgyzstan, authoritarianism, nationalism, legitimization 